\title{
The Influence Factors of Continuance Intention to Use a Music Streaming Application
}

\author{
Diyah Wulandari ${ }^{* 1}$, Usep Suhud ${ }^{2}$,Unggul Purwohedi ${ }^{3}$ \\ ${ }^{1,2,3}$ Faculty of Economics, State University of Jakarta,Jakarta,Indonesia \\ *e-mail:"'1diyahwullandari@gmail.com; ${ }^{2} j o b b e @ u n j . a c . i d ;{ }^{3}$ upurwohedi@unj.ac.id
}

\begin{abstract}
Currently, streaming music applications have a high demand by smartphone users in Indonesia. Streaming music applications is new trend and can't be separated from the people daily life, because of the need for full access, easy and inexpensive music services. This study aimed to find out the factors that influence continuance intention to use a music streaming application. This study uses variable perceived ease of use, perceived enjoyment, entertainment, habit, social influence, satisfaction and continuance intention. The data used in research is primary data obtained from online questionnaires. Sample in this study were 200 respondents streaming music application users from Spotify in the Greater Jakarta area. The sampling technique of this study was non-probability sampling with purposive sampling method. This study uses a quantitative approach through statistical analysis. Tests conducted using Structural Equation Modeling (SEM) with the help of analysis of moment structures (AMOS 24). This result shows that perceived ease of use, perceived enjoyment, and entertainment have a positive and significant effect toward satisfaction. Satisfaction and habit have a positive and significant effect toward continuance intention. Meanwhile social influence has a negative and significant effect toward continuance intention.
\end{abstract}

Keywords - Perceived Ease of Use, Perceived Enjoyment, Entertainment, Habit, Social Influence, Satisfaction, Continuance Intention

\section{INTRODUCTION}

The rapid development of technology from year to year supports the success of an organization in business competition. The easier and faster to get information using technology affects the increase in interactions between individuals to get the information they need. The rapid development of technology makes the growth of Internet users increase. The rapid development in the field of information technology also has an impact on how to listen to music that has undergone many changes. This phenomenon is seen from the tendency of people who prefer to listen to music streaming through digital devices. One of technology that supports to access or play music is a streaming music player application. Streaming is a technology for storing data on audio recordings, video recordings and other multimedia in a realtime.

Currently popular streaming music applications are Joox, Spotify, Deezer, Soundcloud, Apple Music and LangitMusik.This application has different advantages that can attract users to choose the option of using the IJoASER,Volume 2,Issue 2, July, 2019

DOI: 10.33648/ijoaser.v2i2.32

Copyriht: STAI Al-Furqan Makassar,Indonesia

Content License: CC-BY-SA 
streaming music applications. The large number of users of streaming music applications ultimately creates its own trend that continues to evolve with the rapid development of information technology.

Many factors that can affect satisfaction using music streaming application include perceived ease of use, according to Davis [1], perceived ease of use is interpreted as a level where one believes that using the system is not It takes any effort (free from effort). According to Pal and Triyason [2], overall if the streaming music application service is easy to use in every aspect correctly starting from the search feature up to the application display or other factors if there is, it will eventually lead to a sense of Greater satisfaction among users.

Furthermore, in relation to satisfaction, according to Davis [1] perceived enjoyment is an intrinsic motivation whereby the use of information systems is considered enjoyable and enhances comfort. If a user feels enjoyment when using an application or information technology system, it tends to be satisfied with the application. Entertainment can be defined as the extent to which the use of a particular media is entertaining and appealing to its users. More and more users are entertained, it will tend to have a high level of satisfaction, because an interesting entertainment will give users the motivation to use the media more often [3].

Many factors that affect continuance intention using streaming music applications such as satisfaction. Reveal if the need for pleasure is fulfilled and users feel satisfied using the product, then the user will be happy to reuse it. Satisfaction is a very important factor to be aware of for the continuity of an application can last long [3]. Further in relation to continuance of intention, explained that the habit affects continuance intention because behavior habits can produce a pleasant feeling towards a deed, therefore it can increase the continuance of intention [4].

Social influence is defined as an impact of interaction on social networks and also as a major influence of specific behaviors of individuals or groups. Venkatesh et al. [5] states that social influences describe the feelings of users who are thinking of inviting others to use certain systems or technologies. Because there is an invitation from a person or a groupthat requires them to use a system, it is very closely related to the continuation to use the system continuously. Based on the above background, the research hypothesis is formulated as follows: 


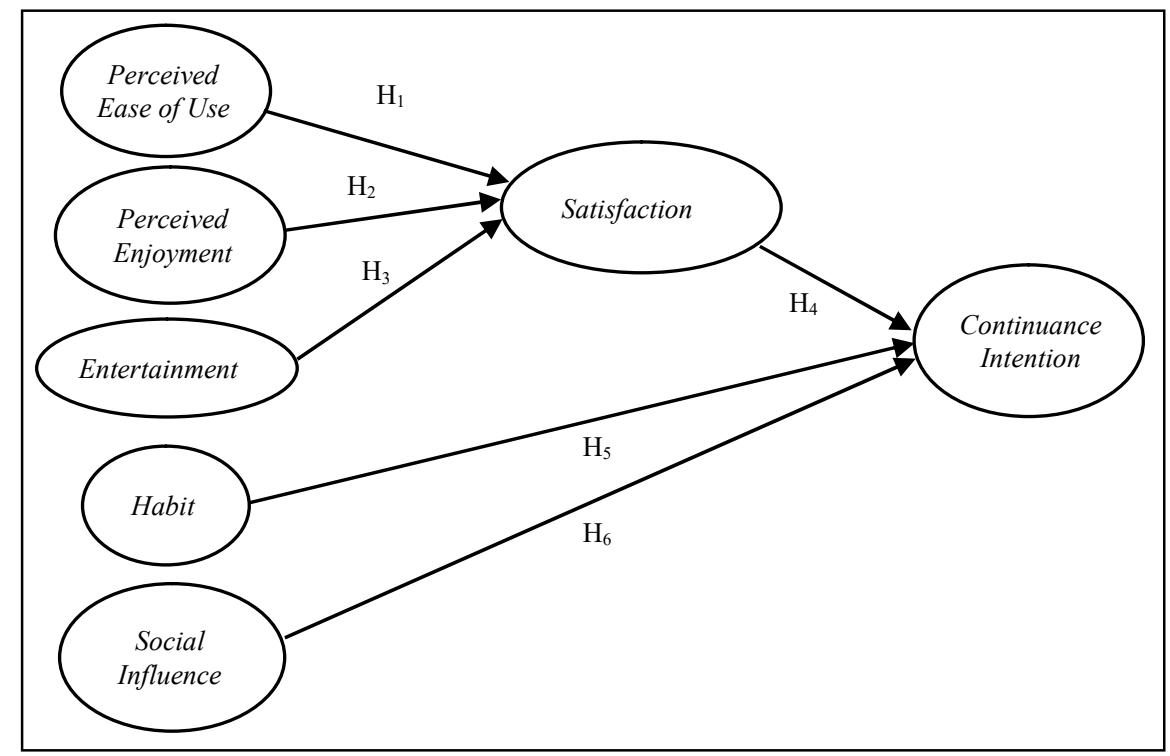

Fig. 1 Research Model

The hypothesis is:

$\mathrm{H}_{1}$ : Perceived Ease of use has a positive effect toward satisfaction of using streaming music applications.

$\mathrm{H}_{2}$ : Perceived enjoyment has a positive effect towardsatisfaction of using streaming music applications.

$\mathrm{H}_{3}$ : Entertainment has a positive effect toward satisfaction of using streaming music applications.

$\mathrm{H}_{4}$ : Satisfaction has a positive effect towardcontinuance intention of using streaming music applications.

$\mathrm{H}_{5}$ : Habit has a positive effect towardcontinuance intention of using streaming music applications.

$\mathrm{H}_{6}$ : Social Influencehas a positive effect toward continuance intention of using streaming music applications.

\section{METHOD}

The research methods used in this study are quantitative methods with the formulation of associative problems. The scope of research specified in accordance with the issues to be researched is streaming music from Spotify. The type of data used in this study is the primary data that researchers acquired by filling out questionnaires by respondents and secondary data obtained by researchers through textbooks, journals, or reference articles. The 
population in this study is the whole community that uses streaming music applications in the Greater Jakarta area.

Sample in this study were 200 respondents streaming music application users from Spotify in the Greater Jakarta area. The sampling technique of this study was non-probability sampling with purposive sampling method. This study uses a quantitative approach through statistical analysis. Tests conducted using Structural Equation Modeling (SEM) with the help of Analysis of Moment Structures (AMOS 24).

\section{III.RESULTS AND DISCUSSION}

\section{A. Validity test}

The testing of the construction validity (indicator) is conducted through Confirmatory Factor Analysis (CFA). According to Hair et al., [6] The validity test with the CFA test is to gauge whether the construct (indicator) is capable or does not reflect the latent variable. The results that meet the criteria are when the Critical Ratio value is $>1.96$ with aProbability Value of $<0.05$. The validity test results can be seen in the table below:

Table 1. Instrument Validity test Results

\begin{tabular}{|c|c|c|c|c|c|c|c|}
\hline & & & 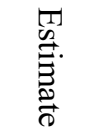 & $\stackrel{n}{\pi}$ & 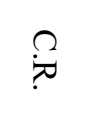 & $\nabla$ & 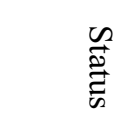 \\
\hline PEOU5 & $<---$ & $\begin{array}{l}\text { Perceived_Ease_ } \\
\text { of_Use }\end{array}$ & .932 & .086 & $\begin{array}{c}10.89 \\
0\end{array}$ & $* * *$ & Valid \\
\hline PEOU1 & $<---$ & $\begin{array}{l}\text { Perceived_Ease_ } \\
\text { of_Use }\end{array}$ & 1.000 & & & & \\
\hline PE3 & $<---$ & $\begin{array}{l}\text { Perceived_Enjoy } \\
\text { ment }\end{array}$ & 1.000 & & & & \\
\hline PE1 & $<---$ & $\begin{array}{l}\text { Perceived_Enjoy } \\
\text { ment }\end{array}$ & 1.057 & .079 & $\begin{array}{c}13.44 \\
0\end{array}$ & $* * *$ & Valid \\
\hline ENT2 & $<---$ & Entertainment & 1.031 & .037 & $\begin{array}{c}27.65 \\
3\end{array}$ & $* * *$ & Valid \\
\hline $\begin{array}{l}\text { HABIT } \\
2\end{array}$ & $<---$ & Habit & .816 & .072 & $\begin{array}{c}11.28 \\
0\end{array}$ & $* * *$ & Valid \\
\hline $\begin{array}{l}\text { HABIT } \\
1\end{array}$ & $<---$ & Habit & 1.000 & & & & \\
\hline SI4 & $<---$ & Social_Influence & 1.000 & & & & \\
\hline SI3 & $<---$ & Social_Influence & .883 & .235 & 3.756 & $* * *$ & Valid \\
\hline $\begin{array}{l}\text { SATIS } \\
2\end{array}$ & $<---$ & Satisfaction & 1.000 & & & & \\
\hline
\end{tabular}




\begin{tabular}{|c|c|c|c|c|c|c|c|}
\hline & & & 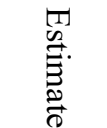 & $\prod_{1}^{\infty}$ & గ్ర & $\nabla$ & $\begin{array}{l}\stackrel{\infty}{\tilde{D}} \\
\overrightarrow{\tilde{E}}\end{array}$ \\
\hline $\begin{array}{l}\text { SATIS } \\
3\end{array}$ & $<---$ & Satisfaction & 1.028 & .052 & $\begin{array}{c}19.80 \\
2\end{array}$ & $* * *$ & Valid \\
\hline CI1 & $<---$ & $\begin{array}{l}\text { Continuance_Inte } \\
\text { ntion }\end{array}$ & 1.000 & & & & \\
\hline $\mathrm{CI} 3$ & $<---$ & $\begin{array}{l}\text { Continuance_Inte } \\
\text { ntion }\end{array}$ & 1.059 & .049 & 21.780 & $* * *$ & Valid \\
\hline ENT1 & $<---$ & Entertainment & 1.000 & & & & \\
\hline $\begin{array}{l}\text { SATIS } \\
1\end{array}$ & $<---$ & Satisfaction & .886 & .041 & $\begin{array}{c}21.58 \\
0\end{array}$ & $* * *$ & Valid \\
\hline
\end{tabular}

\section{B. Reliability Test}

Reliability tests are used to determine the level of reliability of all statements in questionnaires. Results that meet the criteria are when the Construct Reliability value is $<0,5$.

Table 2. Reliability testing results for each variable

\begin{tabular}{ccc}
\hline & Reliabel \\
Perceived Ease of Use & 0,814 & Reliabel \\
Perceived Enjoyment & 0,834 & Reliabel \\
Entertainment & 0,945 & Reliabel \\
Habit & 0,809 & Reliabel \\
Social Influence & 0,768 & Reliabel \\
Satisfaction & 0,934 & Reliabel \\
Continuance Intention & 0,920 & \\
\hline
\end{tabular}

\section{Measurement Model Evaluation}

Analysis of the measurement model is carried out with confirmatory factor analysis (CFA) in all the research and indicators. Prior to further analysis, analysis was conducted on Goodness-of-Fit measurement models. When the measuring model has a Goodness-of-Fit value that satisfies, the measuring model deserves further analysis. 
The suitability of the measurement model with empirical data is measured by the Goodness-of-Fit index (GOF) indicating how well the predefined model generates a covariant matrix between each indicator [7]. The following table shows the Goodness-of-Fit values in the analysis of the measurement model:

Table 3. Model Precision Size Before Dropping

\begin{tabular}{|c|c|c|c|}
\hline 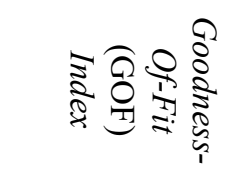 & 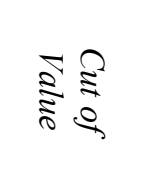 & 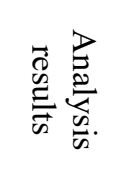 & 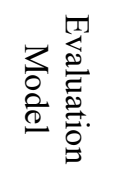 \\
\hline Chi-square & $\begin{array}{l}\text { Expected } \\
\text { Small }\end{array}$ & 585,717 & Fit \\
\hline $\begin{array}{l}\text { Sig. } \\
\text { Probability }\end{array}$ & $\geq 0,05$ & 0,000 & Not Fit \\
\hline CMIN/DF & $\leq 2,00$ & 2,306 & Not Fit \\
\hline GFI & $\geq 0,90$ & 0,821 & Not Fit \\
\hline AGFI & $\geq 0,90$ & 0,771 & Not Fit \\
\hline TLI & $\geq 0,90$ & 0.921 & Fit \\
\hline CFI & $\geq 0,90$ & 0.933 & Fit \\
\hline RMSEA & $\leq 0,08$ & 0.081 & Not Fit \\
\hline
\end{tabular}

Based on the table above shows that from the resulting SEM analysis results are not yet fit. Therefore, the next step is to do the CFA analysis in order to find the best model by using modifications of the model namely by eliminating some indicators that have great value on the modification indices.

Table 4. Model Precision Size After Dropping

\begin{tabular}{|c|c|c|c|}
\hline 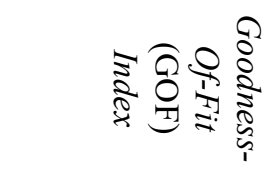 & 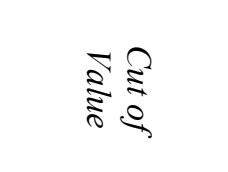 & 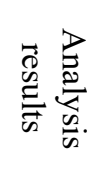 & 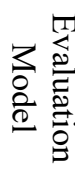 \\
\hline Chi-square & Expected Small & 74,960 & Fit \\
\hline Sig. Probability & $\geq 0,05$ & 0,291 & Fit \\
\hline CMIN/DF & $\leq 2,00$ & 1,086 & Fit \\
\hline GFI & $\geq 0,90$ & 0,952 & Fit \\
\hline AGFI & $\geq 0,90$ & 0,916 & Fit \\
\hline TLI & $\geq 0,90$ & 0,997 & Fit \\
\hline CFI & $\geq 0,90$ & 0,998 & Fit \\
\hline RMSEA & $\leq 0,08$ & 0,021 & Fit \\
\hline
\end{tabular}

Based on the results above, then in this study there are 7 criteria that meet the requirements of goodness of fit namely P-value, GFI, AGFI, 
RMSEA, TLI, CFI and CMIN/DF so that the model can be declared viable and can be used for further analysis.

Table 5. Test result Goodness of Fit Model

\begin{tabular}{|l|c|c|c|}
\hline & & & \\
& & & \\
& & & \\
\hline Chi-square & Expected Small & 79,296 & Fit \\
\hline Sig. Probability & $\geq 0,05$ & 0,316 & Fit \\
\hline CMIN/DF & $\leq 2,00$ & 1,072 & Fit \\
\hline GFI & $\geq 0,90$ & 0,949 & Fit \\
\hline AGFI & $\geq 0,90$ & 0,917 & Fit \\
\hline TLI & $\geq 0,90$ & 0,997 & Fit \\
\hline CFI & $\geq 0,90$ & 0,998 & Fit \\
\hline RMSEA & $\leq 0,08$ & 0,019 & Fit \\
\hline
\end{tabular}

\section{Hypothesis Test}

Hypothesis test decision making by comparing the probability value with a level of significant of $5 \%(\alpha=0.05)$ as well as comparing the value of Critical Ratio (C. R) with the value 1.96 of the hypothesis testing criteria are as follows:

Table 6. Regression Weight Structural Equation Modelling

\begin{tabular}{|c|c|c|c|c|c|c|c|}
\hline & & & 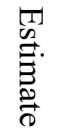 & पू & 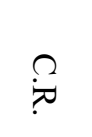 & $\nabla$ & $\begin{array}{l}\stackrel{n}{\vec{*}} \\
\underset{\tilde{D}}{\vec{n}}\end{array}$ \\
\hline $\begin{array}{l}\text { Satisf } \\
\text { action }\end{array}$ & $<--$ & $\begin{array}{l}\text { Perceived_Ease_Of } \\
\text { _Use }\end{array}$ & .227 & .079 & 2.874 & .004 & $\begin{array}{c}\mathrm{H}_{1} \\
\text { Accepted }\end{array}$ \\
\hline $\begin{array}{l}\text { Satisf } \\
\text { action }\end{array}$ & $<---$ & $\begin{array}{l}\text { Perceived_Enjoyme } \\
\text { nt }\end{array}$ & .393 & .169 & 2.319 & .020 & $\begin{array}{c}\mathrm{H}_{2} \\
\text { Accepted }\end{array}$ \\
\hline $\begin{array}{l}\text { Satisf } \\
\text { action }\end{array}$ & $<---$ & Entertainment & 242 & 106 & 2.289 & .022 & $\begin{array}{c}\mathrm{H}_{3} \\
\text { Accepted }\end{array}$ \\
\hline $\begin{array}{l}\text { Conti } \\
\text { nuanc } \\
\text { e_Inte } \\
\text { ntion }\end{array}$ & $<---$ & Satisfaction & .464 & .070 & 6.661 & $* * *$ & $\begin{array}{c}\mathrm{H}_{4} \\
\text { Accepted }\end{array}$ \\
\hline $\begin{array}{l}\text { Conti } \\
\text { nuanc } \\
\text { e_Inte } \\
\text { ntion }\end{array}$ & $<---$ & Habit & .606 & .057 & 10.615 & $* * *$ & $\begin{array}{c}\mathrm{H}_{5} \\
\text { Accepted }\end{array}$ \\
\hline
\end{tabular}

IJoASER,Volume 2,Issue 2, July, 2019

DOI: 10.33648/ijoaser.v2i2.32

Copyriht: STAI AI-Furqan Makassar,Indonesia

Content License: CC-BY-SA 


\begin{tabular}{|c|c|c|c|c|c|c|}
\hline & & $\begin{array}{l}\frac{\pi}{N} \\
\stackrel{0}{E} . \\
\stackrel{0}{0} \\
\stackrel{0}{0}\end{array}$ & $\stackrel{\mathscr{T}}{\Pi}$ & ?ृ & $\nabla$ & $\begin{array}{l}\stackrel{\mathscr{D}}{\vec{D}} \\
\stackrel{\vec{E}}{E}\end{array}$ \\
\hline $\begin{array}{l}\text { Conti } \\
\text { nuanc } \\
\text { e_Inte }<--- \\
\text { ntion }\end{array}$ & Social_Influence & -.122 & .051 & -2.385 & .017 & $\mathrm{H}_{6}$ Rejected \\
\hline
\end{tabular}

\section{IV.CONCLUSION}

Perceived Ease of use has a positiveand significant effect toward satisfaction of using streaming music applications.It means that if an application is easy to learn and use and mastered by its users, it will increase user satisfaction.Perceived enjoyment has a positiveand significant effect toward satisfaction of using streaming music applications.The level of perceived enjoyment owned by a person when using the streaming music applications will affect the level of satisfaction. Entertainment has a positive and significanteffect toward satisfaction of using streaming music applications.If users feel entertained and happy to use the streaming music application then the level of satisfaction will increase.

Satisfaction has a positive effect toward continuance intention of using streaming music applications. The higher the level of user satisfaction, the greater the continuance intention of users to use streaming music application. Habit has a positiveand significanteffect toward continuance intention of using streaming music applications. The existence of the habit that users have will be able to influence continuance intention using streaming music applications. Social Influencehas a negative and significant effect toward continuance intention of using streaming music applications. It means that social influence is not a deciding factor for a person to continue using the streaming music application, but also influenced by one's wishes and needs to continue using the streaming music application.

\section{REFERENCES}

[1] Davis, F.D. (1989). Perceived usefulness, Perceive Ease of Use, and User Acceptance of Information Technology, 13, 319-340

[2] Yahyapour, Nima. 2008. Determining Factors Affecting Intention to Adopt Banking Recommender System. ISSN 1653-0187.

[3] Basak, Ecem., \& Calisir, Fethi. 2015. An Empirical Study on Factors Affecting Continuance Intention of Using Facebook. Journal Computers in Human Behavior, 181-189

[4] Bataineh, Abdallah Q., et al. 2013. Determinants of Continuance Intention to Use Social Networking Sites SNS'S: Studying The Case of 
Facebook. International Journal of Marketing Studies Vol7 No.4, 121135.

[5] V. Venkatesh., M. Morris, G. Davis., \& F. Davis. 2003. User Acceptance of Information Technology: Toward a Unified View. MIS Quarterly. Vol. 27 (3), 425-478.

[6] Hair, J.R. Anderson, R.E, Tatham. R.L \& Black. W.C. 1998. Multivariate Data Analysis. Upper Saddle River: Prentice Hall International Inc.

[7] Hair, J.F. et al. 2007. Multivariate Data Analysis. Sixth Edition. Pearson Prentice Hall

[8] Hsiao, Chun Hua., Chang, Lillian J., \& Tang, Kai-Yu. 2015. Exploring the Influential Factors In Continuance Usage of Mobile Social Apps: Satisfaction, Habit, and Customer Value Perspectives. S07365853(15)00113-6.

[9] Hsiao, Kuo-Lun. 2012. Exploring The Factors That Influence Continuance Intention To Attend One-To-Some Online Courses Via Video Conferencing Software. The Turkish Online Journal of Educational Technology Vol.11 No.4, 7214-7244.

[10] Indrawati., \& Putri, Dianty Anggraini. 2018. Analyzing Factors Influencing Continuance Intention of E-Payment Adoption Using Modified UTAUT 2 Model. International Conference on Information and Communication Technology, 167-173.

[11] Kline, Rex B. 2010. Principles and Practice of Structural Equation Modeling Third Edition. New York: The Guilford Press.

[12] Kotler, Philip dan Keller, Kevin Lane. 2016. Marketing Management 15 Edition. New Jersey: Pearson.

[13] Vijay, T Sai., Prashar, Sanjev., \& Vinita, Sahay. 2017. The Influence of Online Shopping Values and Web Atmospheric Cues on E-Loyalty: Mediating Role of E-Satisfaction. Journal of Theoretical and Applied Electronic Commerce Research, ISSN 0718-1876.

[14] Yahyapour, Nima. 2008. Determining Factors Affecting Intention to Adopt Banking Recommender System. ISSN 1653-0187. 